\title{
Kinerja Reproduksi Induk Sapi Sebelum dan Sesudah Pendampingan pada Kelompok Tani Lembu Agung, Distrik Kurik, Kabupaten Merauke
}

\section{Reproductive Performance of Cow Before and After Assistance at Lembu Agung Farm, Kurik District, Merauke Regency}

\author{
Batseba M.W. Tiro \\ Balai Pengkajian Teknologi Pertanian (BPTP) Papua \\ Jl. Yahim Sentani, Jayapura - Papua
}

\begin{abstract}
Extensive land and diversity of local feed sources allows Papua to have great potential in the development of beef cattle. However, with the traditional livestock breeding system, where livestock is only released and feed still depends on the availability of nature it will certainly affect the productivity of livestock. In addition, farmers have not mastered the feed technology appropriately so that the source of feed has not been utilized optimally to support the growth of livestock. The long dry season in Merauke Regency has an impact on the limited of forage feed in terms of quality and quantity that directly affect the productivity of livestock. On the other hand, the extent of rice cultivation area in Merauke Regency by itself is enough rice cultivation available potentially as beef cattle feed, but the potential has not been optimally utilized. Strategic measures need to be taken such as improving maintenance systems through technological assistance at the farm level. This study aims to present data and information on the reproductive performance of beef cattle before and after assistance in the farming of beef cattle in the Lembu Agung Farmer Group, Kurik District, Merauke Regency. The results of technological assistance at the farm level through improved feeding on parent beef cattle can improve the performance of the parent rerpoduksi that can improve the cows body condition score (BCS) from the range 2 - 2,5 to 3 - 3,5; fix the service per conception $(\mathrm{S} / \mathrm{C})$ value to < 2 ; shortening the calving interval from 18 - 24 months to 13 - 15 months; increase the calf's birth weight to $25-28 \mathrm{~kg}$ and improve changes in body weight.
\end{abstract}

Keywords : Reproductive, Performance, Cow.

\section{PENDAhuluan}

Kabupaten Merauke selain sebagai kawasan pengembangan tanaman padi juga merupakan salah satu sentra pengembangan sapi potong. Sampai tahun 2015, populasi sapi potong di Kabupaten Merauke mencapai 34.521 ekor (BPS Kabupaten Merauke, 2016) dan merupakan populasi terbesar dari total populasi sapi potong di Papua.

Ternak sapi potong merupakan salah satu komoditas yang cukup penting di Provinsi Papua, karena komoditas tersebut memiliki kontribusi baik sebagai sumber pendapatan bagi petani maupun sebagai sumber protein untuk memenuhi kebutuhan gizi dan mencerdaskan masyarakat. Lahan yang cukup luas dan keberagaman sumber pakan lokal memungkinkan Papua memiliki potensi yang besar dalam pengembangan ternak sapi potong. Pusat pengembangan ternak potong di Papua umumnya masih terkonsentrasi pada lokasi transmigrasi yang tersebar di berbagai kabupaten di Provinsi Papua, walaupun petani lokal Papua sudah mulai memelihara ternak tersebut. 
Batseba M.W. Tiro.Kinerja Reproduksi Induk Sapi Sebelum dan Sesudah Pendampingan pada Kelompok Tani Lembu Agung, Distrik Kurik, Kabupaten Merauke

Secara umum, sistem pemeliharaan ternak di Papua masih bersifat tradisional, dimana ternak hanya dilepas dan pakan masih tergantung pada ketersediaan alam tentunya akan berpengaruh pada produktivitas ternak yang dihasilkan. Selain itu peternak belum menguasai teknologi pakan secara tepat sehingga sumber pakan belum dimanfaatkan secara optimal untuk mendukung pertumbuhan ternak. Musim kemarau yang cukup panjang di Kabupaten Merauke berdampak pada terbatasnya hijauan pakan baik dari segi kualitas maupun kuantitas yang secara langsung berpengaruh terhadap produktivitas ternak.

Dilain pihak, luasnya areal pertanaman padi di Kabupaten Merauke dengan sendirinya limbah tanaman padi (jerami dan dedak) cukup tersedia yang berpotensi sebagai pakan sapi potong. Namun selama ini petani belum memanfaatkan jerami padi maupun dedak secara optimal sebagai pakan sapi potong. Berkaitan dengan masalah tersebut, maka diperlukan langkah-langkah strategis seperti perbaikan sistem pemeliharaan dengan jalan menggiatkan usaha penggemukan dan perbibitan yang dikelola oleh masyarakat berskala pengembangan kawasan pada wilayah sentra. Untuk mendukung hal tersebut perlu adanya upaya yang dilakukan dalam meningkatkan populasi dan produksi ternak antara lain melakukan pendampingan teknologi di tingkat petani dengan memanfaatkan sumberdaya lokal baik ternak, lahan, sumber pakan maupun peningkatan sumberdaya manusia dan infrastruktur sebagai penunjang. Pendampingan pengembangan kawasan peternakan didukung oleh inovasi teknologi aplikatif diharapkan mampu meningkatkan produksi dan populasi sapi potong di Papua.

Kajian ini bertujuan untuk menyajikan data dan informasi mengenai kinerja reproduksi induk sapi potong sebelum dan sesudah pendampingan dalam usahatani ternak sapi potong pada kelompok tani Lembu Agung, Distrik Kurik, Kabupaten Merauke.

\section{METODOLOGI}

Kegiatan dilaksanakan pada kelompok tani Lembu Agung, kampung Telaga Sari, distrik Kurik, Kabupaten Merauke. Jumlah responden petani/peternak sebagai sampel yang digunakan dalam kajian ini sebanyak 24 orang. Pada kegiatan pendampingan pengembangan kawasan peternakan sapi potong diterapkan beberapa jenis inovasi paket teknologi Badan Litbang Pertanian seperti pada Tabel 1.

TABEL 1. PENERAPAN INOVASI PAKET TEKNOLOGI PADA KELOMPOK tani Lembu Agung, KabuPaten Merauke.

\begin{tabular}{|c|c|c|c|}
\hline No. & $\begin{array}{c}\text { Inovasi } \\
\text { teknologi }\end{array}$ & Pola pendampingan & $\begin{array}{c}\text { Tanpa } \\
\text { pendampingan }\end{array}$ \\
\hline 1. & Kandang & $\begin{array}{c}\text { Kandang individu, } \\
\text { ukuran } 3 \times 2,5 \mathrm{~m}\end{array}$ & Dilepas \\
\hline 2. & Pakan & $\begin{array}{l}\text { Hijauan 10\% BB } \\
\text { (rumput gajah, } \\
\text { rumput lapangan, } \\
\text { jerami segar, legum } \\
\text { rambat) + dedak 1\% } \\
\text { BB + garam } \\
\text { secukupnya }\end{array}$ & Hijauan $100 \%$ \\
\hline 3. & $\begin{array}{l}\text { Sistem } \\
\text { perkawinan }\end{array}$ & InKA/IB & InKA/IB \\
\hline 4. & $\begin{array}{l}\text { Budidaya } \\
\text { tanaman } \\
\text { pakan ternak }\end{array}$ & $\begin{array}{l}\text { Penanaman rumput } \\
\text { raja di sekitar } \\
\text { kandang }\end{array}$ & - \\
\hline 5. & Pelatihan & $\begin{array}{l}\text { Fermentasi jerami } \\
\text { padi }\end{array}$ & $\begin{array}{l}\text { Fermentasi } \\
\text { jerami padi }\end{array}$ \\
\hline 6. & Diseminasi & $\begin{array}{l}\text { Temu lapang, } \\
\text { Media cetak } \\
\text { (leaflet) }\end{array}$ & $\begin{array}{l}\text { Media cetak } \\
\text { (leaflet) }\end{array}$ \\
\hline
\end{tabular}

Parameter yang diamati meliputi kinerja reproduksi induk (SKT induk, S/C, calving interval, berat lahir) serta perubahan bobot badan induk. sebelum dan sesudah pendampingan. Data yang telah terkumpul dilakukan tabulasi data dan analisis data menggunakan analisis deskriptif kualitatif dan kuantitatif.

\section{Keragaan teknologi eksisting}

Kelompok tani Lembu Agung beranggotakan 24 orang, dengan jenis usaha ternak sapi potong adalah sapi Peranakan Ongole (PO) yang merupakan bantuan (sapi gaduhan) dari Dinas Peternakan. Populasi awal sebanyak 17 ekor dan sudah berkembang menjadi 24 ekor yang terdiri dari betina dewasa 17 ekor, jantan dewasa 4 ekor dan pedet betina 3 ekor, dengan skala pemeliharaan yang relatif rendah yakni rata-rata kepemilikan 1-2 ekor/KK.

\section{HASIL DAN PEMBAHASAN}

Sistem pemeliharaan sapi pada awalnya dipelihara secara intensif pada kandang kelompok yang juga merupakan bantuan Dinas Peternakan. Lantai kandang hanya tanah yang pada saat musim hujan lantainya sangat berlumpur sehingga peternak akhirnya menarik kembali ternaknya, ada 
yang dipelihara disekitar rumah dan sebagian besar dilepas di lahannya masing-masing.

Sistem pemeliharaan yang masih secara semi intensif dengan manajemen yang minim terutama dalam hal penyediaan pakan yang memadai sepanjang tahun. Walaupun ada kandang yang merupakan bantuan dinas tapi tidak dimanfaatkan karena peternak sulit untuk memperoleh pakan. Selama ini peternak hanya mengandalkan ketersediaan rumput alam dan sebagian kecil rumput gajah yang ditanam di areal pematang sawah, dengan jumlah pemberian hijauan hanya sekitar 5-10 kg/ekor/hari. Pada musim kemarau, ketersediaan hijauan sangat terbatas sehingga hal ini sangat berpengaruh terhadap produktivitas ternak. Dimana pada musim kemarau, ternak sapi PO pada pemeliharaan pola petani PBB sapi PO berkisar 0,23 - 0,49 kg/ekor sedangkan dengan teknologi pemberian pakan tambahan (dedak dan gamal) PBB mencapai 0,43 0,71 kg/ekor (Tiro dan Usman, 2015). Terlihat adanya PBB antara sistem pemeliharaan pola petani dengan adanya introduksi teknologi, dimana dengan introduksi teknologi dapat meningkatkan PBB berkisar $30-46 \%$.

\section{Keragaan reproduksi induk sapi potong}

Keragaan reproduksi induk sapi sebelum dan sesusah pendampingan terlihat pada Tabel 2 .

TABEL 2. EFISIENSI REPRODUKSI INDUK SAPI POTONG SEBELUM DAN SESUDAH PENDAMPINGAN PADA KELOMPOK tani Lembu Agung, KabuPaten Merauke.

\begin{tabular}{lcc}
\hline \multicolumn{1}{c}{ Uraian } & $\begin{array}{c}\text { Sebelum } \\
\text { pendampingan }\end{array}$ & $\begin{array}{c}\text { Sesudah } \\
\text { pendampingan }\end{array}$ \\
\hline $\begin{array}{l}\text { Calving } \\
\text { rate (\%) }\end{array}$ & 60 & $80-90$ \\
SKT & $2-2,5$ & $3-3,5$ \\
S/C & \multicolumn{1}{c}{$>2$} & $<2$ \\
Calving & $18-24$ & $13-15$ \\
interval & & \\
(bulan) & $15-18$ & $25-28$ \\
$\begin{array}{l}\text { Berat lahir } \\
\text { (kg) }\end{array}$ & $40-50$ & $70-75$ \\
Calf crop & & $0,5-0,6$ \\
(\%) & $0,3-0,4$ & \\
PBB (kg) & & \\
\hline
\end{tabular}

Skor kondisi tubuh (SKT) induk

Pada Tabel 2, terlihat skor kondisi tubuh (SKT) induk sapi sebelum pendampingan berada dibawah nilai SKT optimum yakni $2-2,5$. Hal ini diduga disebabkan karena rendahnya kualitas pakan yang dikonsumsi, namun dengan adanya perbaikan pakan pada induk terjadi perbaikan SKT induk menjadi 3 - 3,5 dan ini merupakan SKT induk untuk bereproduksi dengan baik. Selain perbaikan SKT, PBB induk setelah pendampingan mencapai $0,6 \mathrm{~kg} / \mathrm{ekor}$.

SKT mencerminkan kualitas dan kuantitas pakan yang diberikan, SKT yang rendah akan mengalami estrus pasca beranak yang lebih lama dibanding SKTnya tinggi. Putro (2009), menyatakan bahwa nilai SKT optimum untuk dapat bereproduksi dengan baik adalah 3,0 - 3,5. Lebih lanjut dijelaskan Putro (2004) yang menyatakan bahwa sapi yang terlalu kurus akan mengalami gangguan respon hormonal, tidak dapat berovulasi dan anestrus. Sedangkan sapi yang terlalu gemuk akan banyak mengalami gangguan dalam proses fertilisasi dan konsepsinya. Oleh karena itu untuk memberi terapi sapi yang mengalami gangguan reproduksi langkah pertama yang harus dilakukan adalah memperbaiki nilai SKT terlebih dahulu sampai kenilai optimum.

Perbaikan pakan induk sapi PO dilakukan dengan memberikan pakan tambahan dedak sebanyak $2 \mathrm{~kg} / \mathrm{ekor} / \mathrm{hari}$. Dedak padi merupakan pakan potensial yang tersedia di lokasi namun selama ini belum dimanfaatkan oleh petani sebagai pakan tambahan untuk ternak sapinya. Selama ini dedak yang ada dijual oleh petani padahal petani sendiri memelihara ternak sapi yang pemberian pakan masih tergantung pada alam.

Dedak halus adalah hasil sisa industri pertanian karena merupakan hasil sisa penggilingan padi (McDowell et al., 1974). Dedak halus merupakan hasil sisa penggilingan padi yang sangat penting, banyak digunakan dalam ransum, cukup disukai ternak dan merupakan sumber vitamin B (Lubis, 1992). Komposisi kimia dedak halus (\%BK) meliputi kandungan protein kasar (PK) sekitar 12,54\%, serat kasar (SK) sekitar 13,49\%, ekstrak eter (EE) sekitar 11,49\%, ekstrak tanpa nitrogen (ETN) sekitar 51,69\%, kandungan total digestible nutrien (TDN) sekitar 72,82\% ( McDowel et al., 1974; Hartadi et al. 2005).

Kekurangan pakan pada sapi-sapi induk merupakan salah satu penyebab penurunan efisiensi reproduksi yang diikuti gangguan reproduksi yang dapat mengakibatkan kemajiran 
Batseba M.W. Tiro.Kinerja Reproduksi Induk Sapi Sebelum dan Sesudah Pendampingan pada Kelompok Tani Lembu Agung, Distrik Kurik, Kabupaten Merauke

pada ternak betina maupun jantan (Hardjopranjoto, 1995). Besarnya kebutuhan bahan kering pakan sapi potong berkisar 2,50 sampai 3,00\% berat badan (Tillman et al., 1998).

Faktor nutrisi sangat berperan terhadap reproduksi. Kekurangan energi dalam pakan berpengaruh terhadap reproduksi yaitu dapat menekan birahi dan ovulasi atau mengurangi jumlah sel telur yang diovulasikan, memperpanjang masa anestrus, menurunkan angka kebuntingan dan mendorong timbulnya anestrus pasca kelahiran. Lebih lanjut dijelaskan kekurangan protein menyebabkan timbulnya birahi yang lemah, birahi tenang, anestrus, kawin berulang (repeat breeder), kematian embrio dini, kelahiran anak yang lemah atau kelahiran prematur (Bearden dan Fuquay, 2004). Jumlah ternak sapi yang diberikan pakan perlakuan pada pola introduksi sebanyak 10 ekor betina. Dari 10 ekor sapi induk yang diberikan perlakuan terdapat satu ekor yang baru beranak ( \pm 1 minggu), dua ekor induk bunting dan tujuh ekor induk yang belum bunting.

\section{Service per conception}

Service per conception (S/C) merupakan representasi fertilitas induk pasca beranak. Sebelum adanya pendampingan teknologi, nilai $\mathrm{S} / \mathrm{C}$ nya di atas 2 . Nilai S/C yang tinggi ini diduga karena peternak belum dapat mendeteksi estrus dengan tepat atau kualitas semennya yang kurang baik. Sistem pemeliharaan yang dilepas akan menyulitkan peternak untuk mendeteksi induk yang sedang estrus sehingga sewaktu di IB kemungkinan waktu estrusnya sudah lewat yang akan berpengaruh terhadap tingkat keberhasilan dari IB. Keberhasilan S/C selain dipengaruhi oleh ketepatan waktu dalam pelaksanaan inseminasi, juga dipengaruhi oleh kualitas semen yang secara langsung dipengaruhi oleh proses penanganan dan penyimpanannya. Proses penyimpanan semen mempunyai pengaruh besar terhadap daya hidup spermatozoa dalam straw. Toelihere (1981), menyatakan bahwa semua usaha untuk mensukseskan pelaksanaan inseminasi buatan dengan penampungan, perlakuan dan pengolahan semen secara sempurna akan sia-sia apabila fase terakhir prosedur inseminasi tidak dilaksanakan sebagaimana mestinya. Pemakaian yang tepat dari semen fertil pada waktu inseminasi adalah esensial untuk kesuburan yang tinggi. Hal ini memerlukan deteksi dan pelaporan estrus yang tepat sehingga inseminasi dapat dilakukan secara cermat oleh tenaga terampil, dan hewan betina yang sehat dalam kondisi reproduksi yang optimal sangatlah penting.

Selain faktor di atas, tingginya nilai S/C juga disebabkan oleh pakan yang dikonsumsi induk dan kondisi induknya sendiri, terlihat dari SKT induk yang berada di bawah tingkat reproduksi yang optimum yakni berkisar $2-2,5$ artinya induk dalam kondisi kurus. Hadisusanto (2008), menyatakan meningkatnya penggunaan jumlah frekuensi (kali) inseminasi buatan (IB) dalam suatu periode inseminasi hingga diperoleh kebuntingan dapat disebabkan oleh beberapa faktor di antaranya (1) kualitas semen beku, (2) teknik inseminasi dan (3) kondisi induk.

Kondisi induk sapi merupakan faktor penting dalam menekan S/C karena memiliki fluktuasi hormonal dan lingkungan uterus yang bervariasi diantara induk. Berlangsungnya proses inseminasi sangat ditentukan oleh keberadaan estrogen yang dihasilkan folikel dominan dalam suatu siklus estrus. Estrogen akan memberikan performan intensitas estrus dan elastisitas cervix sehingga mempermudah dalam inseminasi dan memperlancar progresifitas spermatozoa di dalam uterus (Thatcher, et al., 2006 cit Hadisusanto, 2008).

Namun demikian dengan adanya perbaikan pakan pada induk nilai $\mathrm{S} / \mathrm{C}$ berada di bawah 2. Hal ini menggambarkan bahwa pakan merupakan faktor yang sangat berpengaruh terhadap kondisi ternak dalam hal ini SKT induk juga meningkat menjadi $3-3,5$ yang memungkinkan induk untuk dapat bereproduksi dengan baik.

\section{Calving interval}

Calving interval atau jarak beranak yaitu lama waktu yang diperlukan oleh seekor induk sejak beranak pertama hingga beranak berikutnya. Nilai S/C yang tinggi secara tidak langsung akan berpengaruh terhadap atau calving interval. Di tingkat peternak, jarak beranak induk sapi potong mencapai 18-24 bulan dengan calving rate $60 \%$, dimana menurut peternak jarak beranak yang panjang disebabkan karena terbatasnya pejantan, sehingga pada saat induk berahi pejantannya tidak ada. 
Introduksi teknologi pakan melalui kegiatan pendampingan dapat memperpendek jarak beranak induk sapi potong dari 18 - 24 bulan menjadi 13 - 15 bulan. Pakan yang dikonsumsi induk selama bunting dan masa menyusui akan sangat berpengaruh terhadap estrus kembali setelah beranak yang lebih lanjut berdampak pada jarak beranak. Pada kondisi yang ideal dengan manajemen pemeliharaan yang baik, jarak beranak dapat diperpendek menjadi 12-14 bulan dengan calving rate $70-90 \%$ (Diwyanto, 2015). Jarak beranak dipengaruhi oleh post partum mating, lama bunting dan $\mathrm{S} / \mathrm{C}$, dimana jarak beranak 12 bulan adalah waktu yang paling baik secara ekonomis. Namun menurut Diwyanto et al., (2009), panjangnya jarak beranak lebih banyak dipengaruhi oleh anestrus post partum dan days open, walaupun secara umum terdapat kecenderungan S/C yang tinggi akan menyebabkan jarak beranak menjadi panjang. Jarak beranak yang panjang merupakan kendala inefisiensi produktivitas sapi potong di Indonesia (Winugroho, 2002), yang penyebab utamanya adalah keterlambatan estrus pertama pasca beranak.

\section{Berat lahir}

Berat lahir adalah berat pada saat pedet dilahirkan. Namun, sering dijumpai adanya kesulitan teknis untuk menimbang pedet tepat sesaat setelah dilahirkan, sehingga biasanya berat lahir didefinisikan sebagai berat pedet yang ditimbang dalam kurun waktu kurang dari 24 jam (Hardjosubroto, 1994).

Berat lahir pedet sapi PO sebelum pendampingan berkisar $15-18 \mathrm{~kg}$, namun dengan adanya pendampingan teknologi di tingkat petani yakni melalui perbaikan pakan pada induk dapat meningkatkan berat lahir pedet yang berkisar 25 $28 \mathrm{~kg}$. Adanya perbedaan berat lahir sebelum dan sesudah pendampingan, diduga disebabkan pakan yang dikonsumsi induk selama kebuntingan, dimana sebelum pendampingan pakan yang dikonsumsi induk hanya tergantung pada ketersediaan alam sehingga kuantitas dan kualitas pakan belum dapat memenuhi kebutuhan induk selama kebuntingan sehingga berdampak pada berat lahir yang rendah. Setelah pendampingan teknologi melalui perbaikan pakan pada induk sapi potong, pakan yang dikonsumsi baik kualitas dan kuantitas sudah memenuhi kebutuhan induk sapi selama masa kebuntingan sehingga berat lahir pedet juga semakin tinggi.

Berat lahir pedet dapat bervariasi, hal ini disebabkan beberapa faktor diantaranya adalah bangsa, umur induk, lama bunting, jenis kelamin (Parakkasi, 1999), berat badan induk dan kualitas pakan yang diberikan pada induk terutama bulanbulan akhir kebuntingan (Pudyastuti, 1994).

Besarnya variasi berat lahir pedet sebelum dan sesudah pendampingan dapat dipengaruhi oleh faktor genetik dan lingkungan, namun yang sangat berperan adalah faktor lingkungan dan faktor lingkungan yang mempunyai peran yang besar salah satunya adalah faktor pakan saat induk bunting. Rata-rata berat lahir yang diperoleh selama penelitian tidak berbeda jauh dengan hasil penelitian Talib dan Siregar (1999) yang melaporkan bahwa sapi PO memiliki berat lahir $25,4 \pm 0,8 \mathrm{~kg}$.

\section{Perubahan bobot badan (PBB) induk}

Selain pemberian pakan tambahan dedak, juga dioptimalkan pemanfaatan jerami padi sebagai pakan sapi potong melalui proses fermentasi. Petani yang dulunya tidak terbiasa memberikan pakan jerami padi kepada ternaknya, namun dengan adanya kegiatan pendampingan petani meyadari pentingnya jerami padi sebagai cadangan pakan pada musim kemarau. Apalagi kondisi Merauke yang musim hujannya sangat singkat ( 3 - 4 bulan) dibanding musim kemarau. Pada musim kemarau petani sangat kesulitan mendapatkan hijauan untuk pakan sapi sehingga jerami padi merupakan salah satu pakan alternative yang sangat membantu karena ketersediaannya yang cukup berlimpah. Haryanto et al. (2002), menyatakan bahwa jerami padi yang dihasilkan dapat mencapai 5 ton/ha setiap kali panen, dengan kandungan bahan kering jerami padi segar 40-45\% sehingga potensi produksi jerami padi adalah 2,02,5 ton/ha. Kebutuhan ternak sapi adalah sekitar 6$7 \mathrm{~kg}$ bahan kering jerami per hari untuk sapi dengan bobot hidup $250 \mathrm{~kg}$.

PBB induk sapi potong sebelum pendampingan hanya berkisar $0,3-0,4 \mathrm{~kg} / \mathrm{hari}$, namun setelah adanya pendampingan teknologi dengan adanya perbaikan pakan pada induk PBB induk meningkat menjadi 0,5 - 0,6 kg/hari. Hal ini menunjukkan bahwa, pakan yang dikonsumsi baik kuantitas maupun kualitas akan sangat berpengaruh terhadap kondisi tubuh induk yang 
Batseba M.W. Tiro.Kinerja Reproduksi Induk Sapi Sebelum dan Sesudah Pendampingan pada Kelompok Tani Lembu Agung, Distrik Kurik, Kabupaten Merauke

lebih lanjut akan berdampak pada kinerja induk sapi potong.

\section{KESIMPULAN}

Pendampingan teknologi langsung di tingkat petani dapat memperbaiki kinerja reproduksi induk sapi potong, yakni dapat memperbaiki SKT induk dari kisaran $2-2,5$ menjadi 3 - 3,5; memperbaiki nilai S/C menjadi < 2; memperpendek calving interval dari $18-24$ bulan menjadi 13 - 15 bulan; meningkatkan berat lahir pedet menjadi $25-28 \mathrm{~kg}$ dan memperbaiki PBB induk.

\section{DAFTAR PUSTAKA}

[1] Badan Pusat Statistik Kabupaten Merauke, 2016. Kabuoaten Merauke dalam Angka.

[2] Bearden, J.H., J.W. Fuquay. and S.T. Willard. 2004. Applied Animal Reproduction. $6^{\text {th }}$ Ed. Prentice- Hall Inc, New Jersey. Pp.251.

[3] Diwyanto, K., I. Inouno dan A. Priyanti. 2009. Dampak crossbreeding terhadap kinerja reproduksi sapi potong di Indonesia. Pusat Penelitian dan Pengembangan Peternakan. Badan Penelitian dan Pengembangan Pertanian. Departemen Pertanian, Jakarta.

[4] Diwyanto, K. 2015. Parameter terukur manajeman perkawinan/reproduksi sapi dalam pendampingan integrasi tanaman ternak. Makalah disampaikan pada Temu Koordinasi Pendampingan Integrasi Tanaman Ternak. Puslitbangnak - Bogor.

[5] Hadisutanto, B. 2008. Studi Tentang Beberapa Performaan Reproduksi Pada Berbagai Paritas Induk Dalam Formulasi Masa Kosong (Days Open ) Sapi Perah Fries Holland. (Kasus pada Peternakan Rakyat di Kecamatan Lembang Kabupaten Bandung Barat). Disertasi. Program Pasca Sarjana. Institut Pertanian Bogor.

[6] Hardjosubroto, W. 1994. Aplikasi Pemuliabiakan Ternak di Lapangan. PT. Grasindo. Jakarta.

[7] Hardjopranjoto, S., 1995. Ilmu Kemajiran Pada Ternak. Penerbit Airlangga University Press, Surabaya.

[8] Hartadi, H., S. Reksohadiprodjo dan A.D. Tillman. 2005. Tabel Komposisi Pakan Untuk Indonesia. Gadjah Mada University Press. Yogyakarta.

[9] Haryanto, B., I. Inounu., Arsana. B. Dan K. Diwyanto. 2002. Sistem Integrasi Padi-Ternak. Badan Penelitian dan Pengembangan Pertanian. Departemen Pertanian.

[10] Lubis, D.A. 1992. Ilmu Makanan Ternak. P.T. Pembangunan, Jakarta.

[11] McDowell, L.R., J.H.Courat, J.E. Thomas, and L.E. [9] Harris. 1974. Latin American Tables of Feed
Composition, University of Florida. Gainesville, Florida.

Parakkasi, A. 1999. Ilmu Nutrisi dan Makanan Ternak Ruminansia. Universitas Indonesia, Press. Jakarta.

[12] Pudyastuti, R. 1994. Korelasi Antara Berat Lahir dengan Berat Sapih Serta Pendugaan Berat Badan dari Berbagai Ukuran Tubuh Kambing Peranakan Ettawa pada Kandang Kelompok Pangestu Kabupaten Sleman. Skripsi Sarjana Peternakan. Fakultas Peternakan, Universitas Gadjah Mada, Yogyakarta.

[13] Putro, P.P. 2004. Breeding strategy dalam pengembangan sapi perah rakyat. Seminar Purna Tugas Prof. Soemitro Padmowijoto, Fak. Peternakan UGM. Yogyakarta.

[14] Putro, P.P. 2009. Dampak crossbreeding terhadap reproduksi induk turunannya: Hasil studi klinis. Makalah disampaikan pada Lokakarya Lustrum VIII Fakultas Peternakan, Universitas Gadjah Mada.

[15] Talib, C., dan A. R. Siregar. 1999. Faktor-faktor yang Mempengaruhi Pertumbuhan Pedet Peranakan Ongole dan Crossbreednya dengan Bos indicus dan Bos taurus dalam pemeliharaan Tradisional. Proseding Seminar Nasional Peternakan dan Veteriner. Jilid 1 hal. 200-207.

[16] Tillman, A.D., H. Hartadi, S. Reksohadiprodjo, S. Prawirokusumo dan S. Lebdosoekojo. 1998. Ilmu Makanan Ternak Dasar. Cetakan ke 4. Gadjah Mada University Press. Fakultas Peternakan Universitas Gadjah Mada. Yogyakarta.

[17] Tiro, B.M.W. dan Usman. Pengaruh suplementasi hijauan gamal dan dedak padi terhadap bobot badan sapi pada musim kemarau. Jurnal Ilmu Pertanian Agros. Fakultas Pertanian Universitas Janabadra, Yogyakarta. Vol 17 No. 1, Januari 2015.

[18] Toelihere, M.R. 1981. Inseminasi Buatan pada Ternak. Angkasa Bandung.

[19] Winugroho, M. 2002. Strategi pemberian pakan tambahan untuk memperbaiki efisiensi reproduksi induk sapi. Journal Litbang Pertanian. 21: 19-23. 